\title{
Retrieval of atmospheric optical parameters from ground-based sun-photometer measurements for Zanjan, Iran
}

\author{
A. Bayat, A. Masoumi, and H. R. Khalesifard \\ Department of Physics, Institute for Advanced Studies in Basic Sciences (IASBS), Zanjan, 45137-66731, Iran \\ Received: 29 April 2010 - Published in Atmos. Meas. Tech. Discuss.: 17 June 2010 \\ Revised: 3 May 2011 - Accepted: 5 May 2011 - Published: 11 May 2011
}

\begin{abstract}
We are reporting the results of ground-based spectroradiometric measurements on aerosols and water vapor in the atmosphere of Zanjan for the period of October 2006 to September 2008 using a CIMEL CE318-2 sun-photometer. Zanjan is a city in Northwest Iran, located at $36.70^{\circ} \mathrm{N}$, $48.51^{\circ} \mathrm{E}$, and at an altitude of $1800 \mathrm{~m}$ a.m.s.l. (above mean sea level). The spectral aerosol optical depth, Ångström exponent, and columnar water vapor have been calculated using the data recorded by the sun-photometer through the direct measurements on the sun radiance (sun-mode). The average values of aerosol optical depth at $440 \mathrm{~nm}$, columnar water vapor, and the Ångström exponent, $\alpha$, during the mentioned period are measured as, $0.28 \pm 0.14,0.57 \pm 0.37$ $\mathrm{cm}$ and $0.73 \pm 0.30$, respectively. The maximum (minimum) value of the aerosol optical depth was recorded in May 2007 (November 2007), and that of columnar water vapor, in July 2007 (January 2008). Using the least-squares method, the Ångström exponent was calculated in the spectral interval 440-870 nm along with $\alpha_{1}$ and $\alpha_{2}$, the coefficients of a second order polynomial fit to the plotted logarithm of aerosol optical depth versus the logarithm of wavelength. The coefficient $\alpha_{2}$ shows that most of the aerosols in the Zanjan area have dimensions larger than 1 micron. The calculated values for $\alpha_{2}-\alpha_{1}$ indicate that $80 \%$ of the aerosols are in the coarse-mode $(>1 \mu \mathrm{m})$ and $20 \%$ of them are in the finemode $(<1 \mu \mathrm{m})$. Comparison of $\alpha_{2}-\alpha_{1}$ for the atmosphere over Zanjan with other regions indicates dust particles are the most dominant aerosols in the region.
\end{abstract}

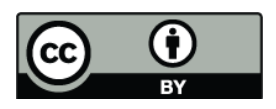

Correspondence to: A. Bayat (a_bayat@iasbs.ac.ir)

\section{Introduction}

Iran, a country in the Middle East, is located within the Earth's dust belt. The Tigris and Euphrate basins in the west, and the Arabian Peninsula in the south are the main sources for frequently observed dust events in these regions (Prospero et al., 2002). Even though other observations show that other sources within the country, such as the Qom lake (a salt-covered playa) in the center (Mortazavi, 2009), or Hamoun Jaz-Murian in the south east have some impact on the atmospheric aerosols in Iran (Leon and Legrand, 2003), outside sources are more dominant.

Zanjan is a city in Northwest $\operatorname{Iran}\left(36.70^{\circ} \mathrm{N}, 48.51^{\circ} \mathrm{E}, 1\right.$ $800 \mathrm{~m}$ a.m.s.l), located in a mountainous region. It is subject to frequent dust storms especially in mid and late spring as well as summer and early fall. A free horizon terrace and excellent weather conditions, with $2850 \mathrm{~h}$ of sun per year (Samimi and Anvari, 1997), make this area adequate for aerosol monitoring with remote sensing instruments. The aerosol optical depth (AOD), which is the integral of the optical extinction coefficient of the atmospheric aerosols from the surface to the top of the atmosphere, is an important parameter for visibility degradation (due to atmospheric pollution), solar radiation extinction, climate effects, and tropospheric corrections in remote sensing (Dubovik et al., 2002). Here we are reporting the measurements on the aerosol optical depth of the atmosphere of Zanjan using an automatic sun-tracker sun-photometer (SPM) CIMEL CE318-2. The measurements were carried out in the period between October 2006 and the end of September 2008.

Data recorded in the $936 \mathrm{~nm}$ wavelength channel of the sun-photometer in combination with the measurements in the $870 \mathrm{~nm}$ and $1020 \mathrm{~nm}$ wavelength channels provides

Published by Copernicus Publications on behalf of the European Geosciences Union. 
information on the water vapor column (CWV; Halthore et al., 1997). The Ångström exponent, $\alpha$, is often used as a qualitative indicator of aerosol particle size (Ångström, 1929). Using the least-squares method, $\alpha$ was calculated in the spectral interval $440-870 \mathrm{~nm}$. We also used a second order polynomial fit to the plotted logarithm of AOD versus the logarithm of wavelength (Kaskaoutis et al., 2007) to have a more accurate measure of aerosol size distribution in the atmosphere of Zanjan.

In the next parts of this manuscript, after introducing the measurement instrument in Sect. 2, the theoretical basis of the work and calculations will be presented in Sect. 3. Section 4 contains the results of the measurements, and finally the work is concluded in Sect. 5 .

\section{Measurements and instrumentation}

The SPM records the sun and sky radiance on the photometer surface at eight wavelength channels, 440, 670, 870, 936, and $1020 \mathrm{~nm}$ where the $870 \mathrm{~nm}$ channels consist of one nonpolarized and three polarized channels to provide the Stokes parameters. These channels are selected wavelengths that have minimal molecular absorption except for the $936 \mathrm{~nm}$ channel that matches one of the water vapor absorption lines (Holben et al., 1998).

The SPM is installed at the Institute for Advanced Studies in Basic Sciences, IASBS, $\left(36.70^{\circ} \mathrm{N}, 48.51^{\circ} \mathrm{E}\right.$, $1800 \mathrm{~m}$ a.m.s.l) and from now on we call it the IASBS site. The SPM was not registered in the AERONET for the mentioned period of data recording. The SPM at the IASBS site was operational since the start of this work (4 October 2006). The factory calibration parameters of the SPM has been used during the first year of the measurements and we used the Langley plots to calibrate the instrument for the rest of the time period (Holben et al., 1998). The required data for drawing the Langley plots were recorded on 7-11 October 2008 when the SPM was installed on the Dinava mountains $\left(34.1^{\circ} \mathrm{N}, 50.7^{\circ} \mathrm{E}\right)$ at an elevation of $3070 \mathrm{~m}$ a.m.s.l. Dinava is isolated from most local sources of aerosols and provides a very stable aerosol and radiance regime in the morning. The Langley plots were drawn for optical air mass between 5 and 2 in the morning. As a result of this calibration, the factory calibration constants at $440,670,870$, 936 and $1020 \mathrm{~nm}$ were changed by $+6 \%,+6 \%,+5 \%,-7 \%$ and $+3 \%$, respectively. It should be mentioned that the modified Langley plot was used to find the calibration constant at $936 \mathrm{~nm}$ wavelength channel (Bruegge et al., 1992).

To extract the cloud free data from the SPM recordings, the AERONET cloud-screening algorithm (Smirnov et al., 2000) has been used here. This algorithm removes all the noises that are creating negative AOD's (i.e. AOD $<-0.01$ ) and it considers that a cloud free atmosphere should be stable during a time scale of $1 \mathrm{~min}$. The algorithm removes all those recordings that are not in the limits of $\overline{\mathrm{AOD}}(440 \mathrm{~nm})$

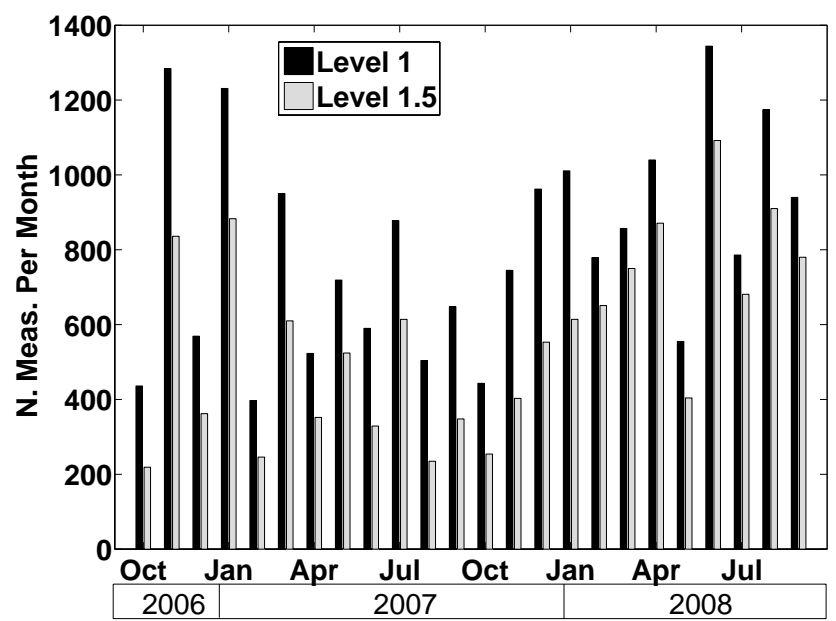

Fig. 1. Number of AOD measurements per month at the IASBS site, October 2006 to September 2008, level 1.0 (raw data) and 1.5 (cloud free data).

$\pm 3 \sigma$ where $\overline{\mathrm{AOD}}(440 \mathrm{~nm})$ stands for the daily average of AOD $(440 \mathrm{~nm})$ and $\sigma$ is the standard deviation. The same rule also holds for calculated Ångström exponents. The number of raw measurements during the whole period of data recording was 19365. After removing the cloud screened data by using the mentioned algorithm, the number of cloud free and valid AOD observations was 13627 . The number of measurements for every month in this period is presented in Fig. 1, both for level 1.0 (raw data) and 1.5 (cloud-free). During the summer, the number of monthly cloud-free measurements was 790 on average, and could be as high as 1150 (around 40 measurements per day), whereas during the winter months the number of cloud-free observations per month was around 400 .

\section{Methods}

\subsection{Aerosol optical depth}

Atmospheric transmittance is a function of the attenuation of extra-terrestrial irradiance by scattering and absorption. When the direct beam is measured over a narrow bandpass (strictly, monochromatic radiation) the Beer-LambertBouguer attenuation law holds and the instantaneous, total optical depth for that wavelength, $\tau(\lambda)$, can be derived from:

$I(\lambda)=\frac{I_{0}(\lambda)}{R^{2}} \exp (-m \tau(\lambda))$,

where, $I(\lambda)$ is the solar radiance over the SPM detector and $I_{0}(\lambda)$ is a measure of solar radiation behind the atmosphere that can be found by drawing a Langley plot for the instrument (Holben et al., 1998). $R$ is the mean Earth-Sun distance in Astronomical Units at the time of observation and $m$ is the relative optical air mass, which is approximated 
as the secant of the solar-zenith angle (Kasten and Young, 1989). The total optical depth, $\tau(\lambda)$, is the result of attenuation by molecules (Rayleigh scattering), aerosol scattering, and absorption by atmospheric gases like water vapor, ozone and other uniformly mixed gases. Each of these components can be separated. The Rayleigh optical depth, $\tau_{R}(\lambda)$, as a part of $\tau(\lambda)$ is readily calculated, depending only on the wavelength and barometric pressure at the surface (Holben et al., 1998). Daily averaged values of surface pressure data recorded on an automatic weather station (CIMEL, Model: ENERCO 408p) that is located in IASBS site, have been used in these calculations. The ozone optical depth, $\tau_{\mathrm{O}}(\lambda)$, in $670 \mathrm{~nm}$ is estimated by multiplying the daily averaged observation values of ozone column abundance in Dobson units (DU or matm-cm) obtained from TOMS database by the absorption coefficients in $670 \mathrm{~nm}$ (Burrows et al., 1999; McPeters et al., 1998). Since $\mathrm{NO}_{2}$ has a very small effect on the atmospheric optical depth it has not been taken into account in the calculations. The aerosol optical depth, $\tau_{\mathrm{a}}(\lambda)$, can be obtained through:

$\tau_{\mathrm{a}}(\lambda)=\tau(\lambda)-\tau_{\mathrm{R}}(\lambda)-\tau_{\mathrm{O}}(\lambda)$,

where $\tau_{\mathrm{O}}(\lambda)$ only is calculated for $\lambda=670 \mathrm{~nm}$ and for other wavelengths, 440, 870 and $1020 \mathrm{~nm}$ only the Rayleigh optical depth has been considered (Holben et al., 1998).

\subsection{Water vapor}

Extraction of the value of the atmospheric columnar water vapor from the SPM measurements generally depends on measurements in the $936 \mathrm{~nm}$ channel of the SPM that coincides with one of the water vapor absorption bands. The aerosol effect is removed by interpolation between the two adjacent bands of the SPM (870 and $1020 \mathrm{~nm}$ wavelength channels) (Halthore et al., 1997) and subtracting the calculated $\tau_{\mathrm{a}}(936)$ from the measured $\tau(936)$. In this case, Eq. (1) is not valid anymore since the exponential attenuation applies strictly to monochromatic radiation and is invalid across the broad region of the water vapor absorption band.

Atmospheric radiation transmission in the water vapor band $T_{\mathrm{w}}$ can be modelled as (Halthore et al., 1997),

$T_{\mathrm{w}}=\exp \left(-a m^{b} w^{b}\right)$

where $w$ is the water vapor vertical column abundance measured in $\mathrm{cm}$ and $a$ and $b$ are constants that depend on the wavelength, transmittance spectrum of the SPM filter, and atmospheric conditions (temperature-pressure lapse and the vertical profile of water vapor band).

Halthore et al. (1997) showed that for a narrow band (less than $10 \mathrm{~nm}$ full width at half maximum) filter, $a$ and $b$ parameters are not sensitive to the mentioned atmospheric conditions. In other words, these parameters are the same for all similar instruments that are equipped with narrow band filters and installed at different geographical positions. For the instrument that was used here, $a=0.6034$ and $b=0.5746$ (Smirnov et al., 2004).

\subsection{The Ångström exponent}

Ångström (1929) proposed an empirical formula to approximate the spectral dependence of the atmospheric extinction caused by aerosols:

$\tau_{\mathrm{a}}(\lambda)=\beta \lambda^{-\alpha}$,

where $\beta$ is the Ångström turbidity coefficient which is equal to the AOD at $\lambda=1 \mu \mathrm{m}$, and $\alpha$ is the widely known Ångström exponent.

A more precise empirical relationship between the aerosol extinction coefficient and the wavelength is obtained by using a second-order polynomial (King and Byrne, 1976),

$\ln \tau_{\mathrm{a}}(\lambda)=\alpha_{0}+\alpha_{1} \ln \lambda+\alpha_{2}(\ln \lambda)^{2}$,

The coefficient $\alpha_{2}$ accounts for a curvature often observed in sun-photometry measurements when the logarithm of $\tau_{\mathrm{a}}(\lambda)$ is plotted against the logarithm of wavelength. The curvature can be an indicator of the aerosol particle size. A negative (positive) curvature indicates aerosol size distribution dominated by fine (coarse) mode particles (Eck et al., 2001; Schuster et al., 2006).

In retrieving the data recorded by a SPM, the second-order polynomial fit (Eq. 5) has been applied to the AOD values at three wavelengths 440,675 , and $870 \mathrm{~nm}$. The AODs at $1020 \mathrm{~nm}$ are not included because of possible water vapor absorption effects at that wavelength, resulting in inaccuracies in the computation of the second order polynomial fit and estimation of the values of $\alpha_{1}$ and $\alpha_{2}$ parameters (Eck et al., 2001).

Schuster et al. (2006) reported that for $\alpha_{2}-\alpha_{1}<1$, aerosol size distributions are dominated by the coarse-mode $(>1 \mu \mathrm{m})$ aerosols. The occurrence of $\alpha_{2}-\alpha_{1}>2$ represents an aerosol size distributions dominated by fine-mode $(<1 \mu \mathrm{m})$ particles and when $1<\alpha_{2}-\alpha_{1}<2$ most of the aerosols are in the finemode.

Holben et al. (1998) found that the resolution of AOD measurements is 0.01-0.02 for calibrated AERONET instruments. For the Langley plots that we have used during the 2nd year of the measurements, we almost have the same resolution. The resolution in $\alpha, \alpha_{1}$, and $\alpha_{2}$ values is proportional to $\frac{\Delta \tau_{i}}{\tau_{i}}$ and implicitly dependent on the air mass (Eck et al., 1999). Therefore at small AOD values the uncertainties in $\alpha, \alpha_{1}$, and $\alpha_{2}$ increase considerably (Eck et al., 1999) and the error in determination of the filter wavelengths becomes negligible (Toledano et al., 2007). 


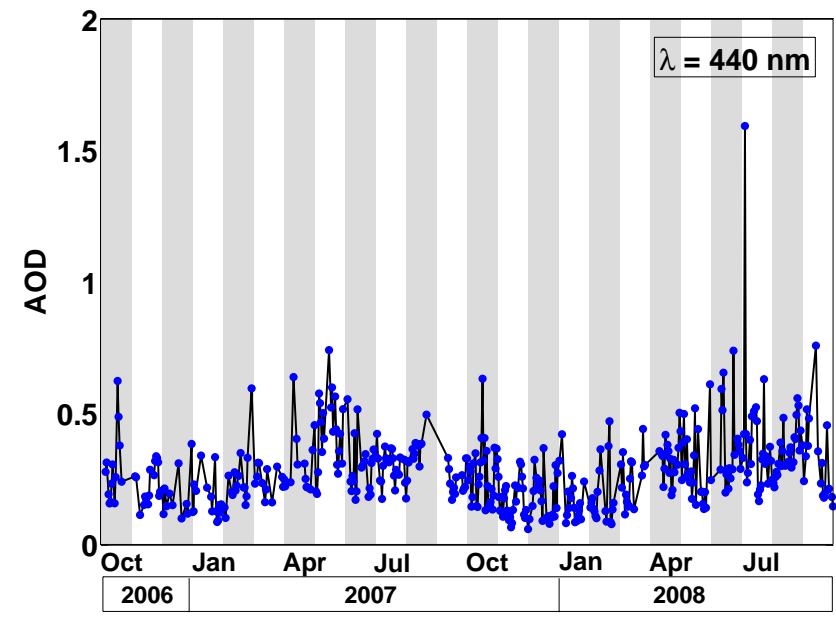

Fig. 2. Temporal evolution of AOD $(440 \mathrm{~nm})$ daily averages in Zanjan, October 2006 to September 2008, the IASBS site.

\section{Results}

In this work, only the SPM data in the sun-mode have been used. In the sun-mode, the SPM looks directly at the sun at a $1.2^{\circ}$ field of view and measures the atmospheric optical depth.

\subsection{Aerosol optical depth climatology}

Figure 2 shows the daily average of AOD $(440 \mathrm{~nm})$ variations for two years of available cloud-free data. The occurrence of high turbidity events is higher during the spring, as can be seen for example in 2007, where consecutive peaks have resulted from the considerable number of desert dust events between April and June. Furthermore, in this figure, an increase over the AOD background value can be seen during the late spring and summer.

Once the main features of the individual measurements were observed, daily and monthly averages were calculated in order to obtain climatological values for the AOD. Figure 3 shows the AOD monthly averages for the $440 \mathrm{~nm}$ channel during the two years. Error bars indicate the standard deviation within the month.

The pattern of low AOD during winter times is clear in Fig. 3, where the minimum value of $\tau_{\mathrm{a}}(440)=0.14$, has occurred in November 2007. These low levels of aerosol loading are due to more frequent rains in winter and few occurrences of dust events. On the other hand, during spring and summer, the AOD values have increased considerably. During April to September, monthly average values of $\tau_{\mathrm{a}}(440)$ are larger than 0.25 and even reach to 0.40 in May 2007, with much higher variability as indicated by larger error bars. Referring to Fig. 3, one can see that the maximum AOD values occur in late spring and summer while its minimum values occur in late autumn and early winter.

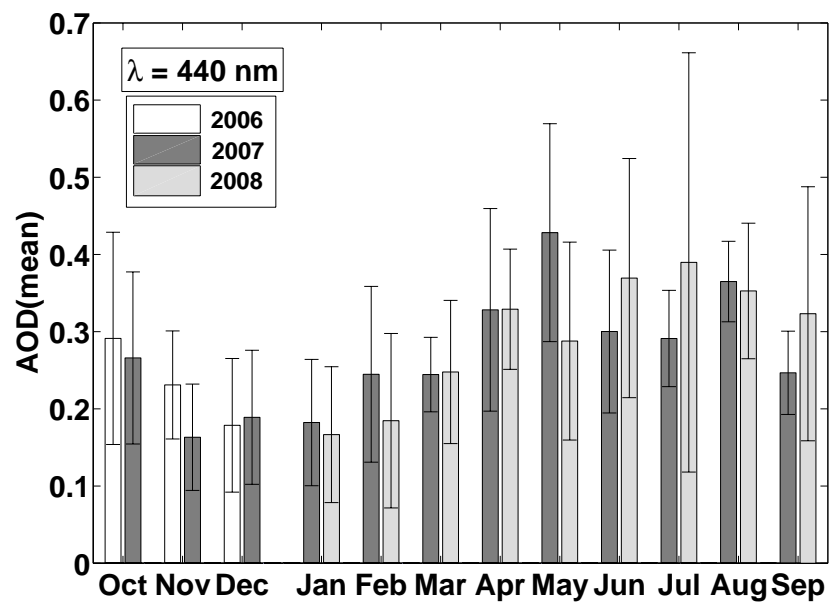

Fig. 3. Temporal evolution of AOD $(440 \mathrm{~nm})$, monthly averages in Zanjan for the period of October 2006 to September 2008, the IASBS site.

Table 1. Two typical dust events recorded on 22 June 2008 and 3 July 2008. The AOD values were extracted from MODIS Deep Blue data and the IASBS site measurements.

\begin{tabular}{lccc}
\hline Date & $\begin{array}{c}\text { Daily } \\
\text { averaged } \\
\text { AOD at } \\
440 \mathrm{~nm} \\
\text { IASBS } \\
\text { site }\end{array}$ & $\begin{array}{c}\text { Daily } \\
\text { averaged } \\
\text { AOD at } \\
\text { 550 } \mathrm{nm} \\
\text { MODIS } \\
\text { Deep } \\
\text { Blue }\end{array}$ & $\begin{array}{c}\text { Horizontal } \\
\text { visibility } \\
(\mathrm{km})\end{array}$ \\
& & $\begin{array}{c}\text { Zanjan } \\
\text { Met. } \\
\text { office }\end{array}$ \\
\hline 21 June 2008 & 0.29 & 0.34 & 15 \\
22 June 2008 (dust event) & 0.74 & 0.85 & 5 \\
23 June 2008 & 0.34 & 0.46 & 10 \\
\hline 2 July 2008 & 0.42 & 0.52 & 12 \\
3 July 2008 (dust event) & 1.59 & 1.68 & 7 \\
4 July 2008 & 0.42 & 0.46 & 10 \\
\hline
\end{tabular}

The turbidity of the atmosphere increases because of the characteristic dry spring and summer seasons in Zanjan area and occurrence of dust events originated from the neighboring dust sources like the Tigris and Euphrates basin. These events are mostly happening every spring and summer, but their number and intensity shows strong variability from year to year. Table 1 depicts the observation of two typical dust events in 22 June 2008 and 3 July 2008. The table contains daily averaged AOD values extracted from MODIS Deep Blue recordings at $550 \mathrm{~nm}$ and the IASBS site measurements at $440 \mathrm{~nm}$ as well as the horizontal visibility data reported by the Zanjan Meteorological Office for the mentioned dates. Looking at the daily average values of AOD at $440 \mathrm{~nm}$ (IASBS site) and $550 \mathrm{~nm}$ (MODIS) in Table 1, one can see that the events duration is about one day and this is 
Table 2. AOD statistics for the 2-year data series in Zanjan in all 4 AOD channels, CWV at $936 \mathrm{~nm}, \alpha, \alpha_{2}$ and $\alpha_{2}-\alpha_{1}$ : the average, standard deviation (STD), minimum, and maximum. Total number of days with valid data: 448 .

\begin{tabular}{lccccccrc}
\hline & $\mathrm{AOD}_{440}$ & $\mathrm{AOD}_{670}$ & $\mathrm{AOD}_{870}$ & $\mathrm{AOD}_{1020}$ & $\mathrm{CWV}(\mathrm{cm})$ & $\alpha$ & $\alpha_{2}$ & $\alpha_{2}-\alpha_{1}$ \\
\hline Average & 0.28 & 0.20 & 0.18 & 0.17 & 0.57 & 0.73 & 0.51 & 0.74 \\
STD & 0.14 & 0.13 & 0.13 & 0.12 & 0.37 & 0.30 & 0.25 & 0.30 \\
Min & 0.06 & 0.04 & 0.03 & 0.03 & 0.01 & 0.01 & -0.19 & 0.01 \\
Max & 1.59 & 1.59 & 1.57 & 1.54 & 1.55 & 1.58 & 1.13 & 1.58 \\
\hline
\end{tabular}

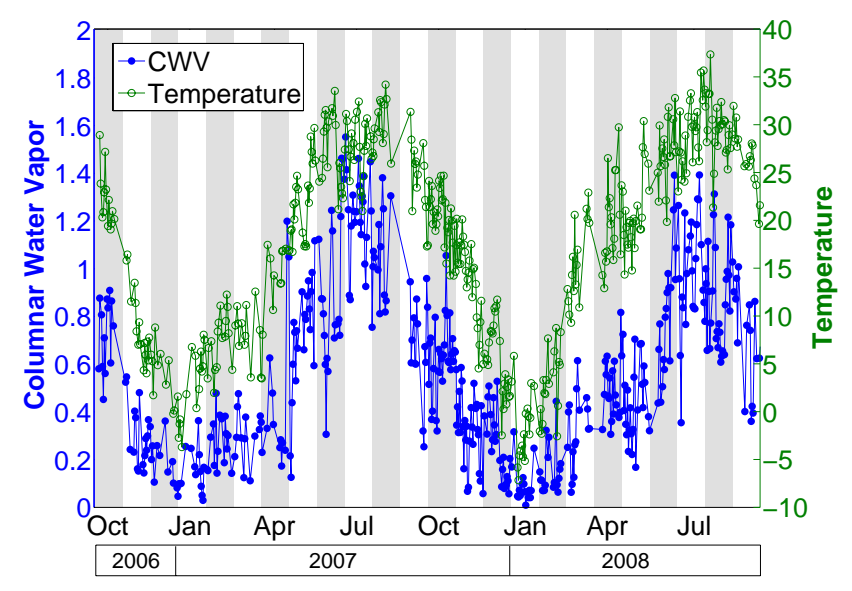

Fig. 4. Temporal evolution of daily averaged CWV (936 nm) and temperature in Zanjan, October 2006 to September 2008, the IASBS site.

the typical duration of the dust events that are happening in this region.

The described behavior is more or less the same for all wavelength channels of the SPM (not shown).

The general statistics for the whole data series is summarized in Table 2. To have an estimation of AOD variability at different wavelengths, one may refer to standard deviations of the recorded AODs at different wavelength channels where they are larger for lower wavelengths (Table 2). Also looking at the average values of AOD in Table 2, a moderate wavelength dependency can be observed.

\subsection{Columnar water vapor climatology}

The temporal resolution of the recorded data set allows one to study the temporal evolution of the CWV. Figure 4 shows the daily averaged CWV $(936 \mathrm{~nm})$ variations along the two years for the available cloud-free data. The daily averages of the temperature, recorded by the SPM for the mentioned period are also shown in Fig. 4. The results show that the maximum CWV occurred in July and the minimum in January, both for 2007 and 2008.

Considerable increase of the temperature during the summer (up to $37^{\circ} \mathrm{C}$ ) causes high levels of CWV in this season.

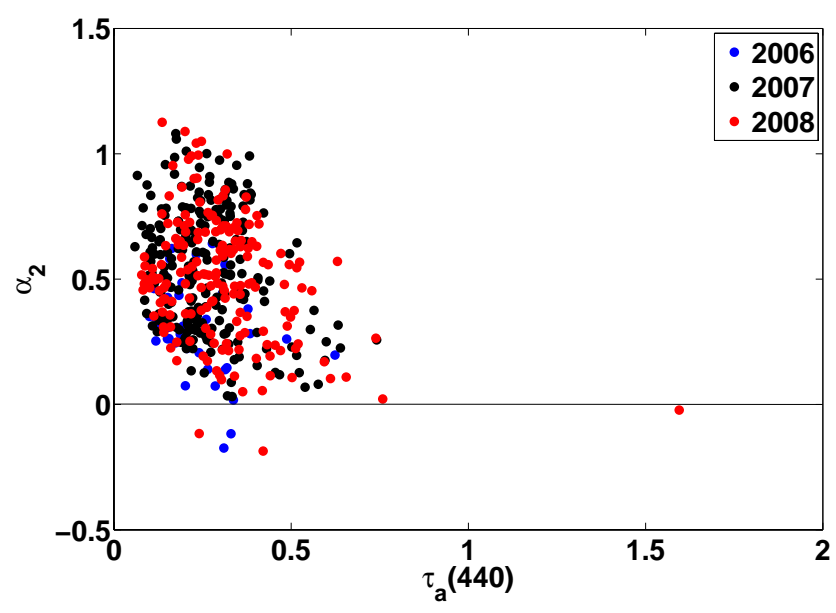

Fig. 5. Correlation between the coefficient $\alpha_{2}$ computed in the spectral interval $440-870 \mathrm{~nm}$ and AOD $(440 \mathrm{~nm})$, the IASBS site, October 2006 to September 2008 .

The average CWV is $0.57 \mathrm{~cm}$ for the whole period of data recording.

\subsection{Aerosol classification, the Ångström exponent}

Since the spectral shape of the extinction is related to particle size, the Ångström exponent is commonly used as an indicator of the predominant aerosol size (type) (Ångström, 1929). But more than this, as it discussed in Sect. 3.3, $\alpha_{1}$ and $\alpha_{2}$, the coefficients of a second order polynomial fit to the plotted logarithm of AOD versus the logarithm of wavelength, have been used here to have a more accurate measure of the aerosol size distribution. Variations of $\alpha_{2}$ and $\alpha_{2}-\alpha_{1}$ versus AOD are more precise tools for aerosol classification (Kaskaoutis et al., 2007). While the AOD gives information about the aerosol loading, and $\alpha_{2}$ and $\alpha_{2}-\alpha_{1}$ are related to the aerosol size (type), joint analysis of these parameters makes interpretation of the data possible (Kaskaoutis et al., 2007). The correlation between $\alpha_{2}$ and AOD (440 nm) provides information on the atmospheric conditions under which the spectral variation of $\alpha_{2}$ is negligible. Therefore, the spectral variation of AOD can be accurately described by the simple Ångström formula. 


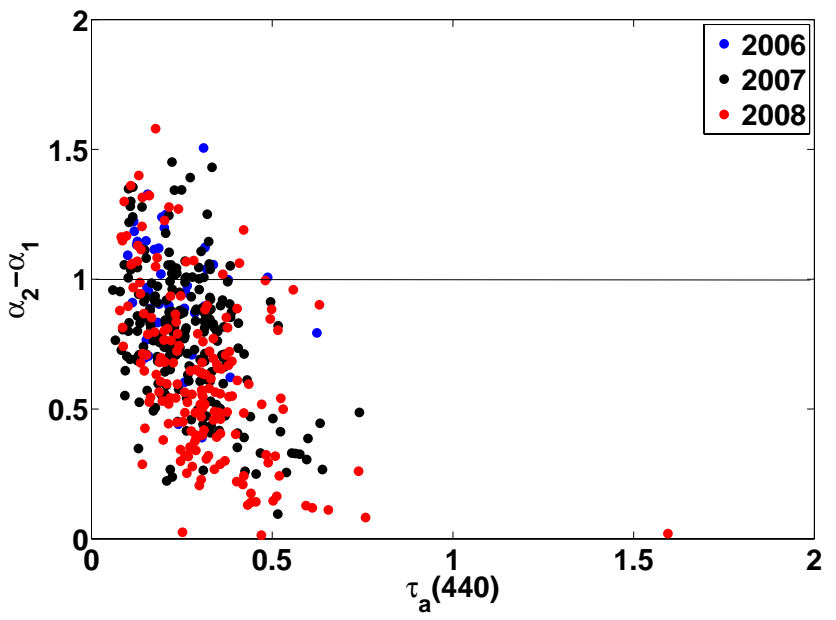

Fig. 6. Correlation between the coefficient $\alpha_{2}-\alpha_{1}$ computed in the spectral interval $440-870 \mathrm{~nm}$ and AOD $(440 \mathrm{~nm})$, the IASBS site, October 2006 to September 2008.

Figure 5 shows the correlation between the coefficient $\alpha_{2}$ computed in the spectral interval $440-870 \mathrm{~nm}$ and the measured AOD $(440 \mathrm{~nm})$, for the IASBS site, from October 2006 to September 2008. There is a decreasing trend in $\alpha_{2}$ with increasing AOD $(440 \mathrm{~nm}) . \alpha_{2}$ values presented in Fig. 5 indicate that most aerosols in the atmosphere of Zanjan are in the coarse-mode.

In Fig. 6, $\alpha_{2}-\alpha_{1}$ values are plotted against AOD (440 nm) for the IASBS site during the mentioned period.

Kaskaoutis et al. (2007) have reported the variations of $\alpha_{2}-\alpha_{1}$ versus the AOD for four different AERONET sites: Alta Floresta (Brazil), a rural site directly influenced by biomass burning smoke during the fire season; Ispra (Italy), an urban/industrial area with significant anthropogenic and industrial activities; Nauru, a remote island in the tropical Pacific characterized by very small aerosol loading; and Solar Village (Saudi Arabia), a continental remote site with significant contribution of desert dust particles. Our results in Fig. 6 show a considerable similarity with the superposition of reported data from Solar Village and Ispra with a higher weight $(\sim 0.8)$ for data from the Solar Village and a lower weight $(\sim 0.2)$ for data from Ispra (Table 3 ).

It should be noted that Zanjan is located in a mountainous area where the two mountain chains, Alborz (northeast to northwest) and Zagros (northwest to south), join together on the Iranian plateau. These mountain chains as barriers, block the humid winds from either the Caspian or the Mediterranean seas. Hence we do not expect to observe maritime aerosols in this region. Also sources for biomass burning aerosols like deep forests are not close to this region. Therefore the results in Fig. 6 and Table 3 are not far from our expectation. In result one may conclude that, dust and anthropogenic aerosols are the main sources of the aerosol in the atmosphere of Zanjan. The calculated values of $\alpha_{2}-\alpha_{1}$
Table 3. Abundance of $\alpha_{2}-\alpha_{1}$ calculated values for Solar Village, Ispra (Kaskaoutis et al., 2007), and IASBS.

\begin{tabular}{lrrr}
\hline & Solar Village & Ispra & IASBS \\
\hline$\alpha_{2}-\alpha_{1}<1$ & $94.6 \%$ & $15.5 \%$ & $80 \%$ \\
$1<\alpha_{2}-\alpha_{1}<2$ & $3.9 \%$ & $63.5 \%$ & $20 \%$ \\
$\alpha_{2}-\alpha_{1}>2$ & $1.5 \%$ & $21 \%$ & $0 \%$ \\
\hline
\end{tabular}

show that $80 \%$ of the aerosols in Zanjan's atmosphere are in the coarse-mode and $20 \%$ in the fine-mode (Table 3). Also this is in agreement with the weights $\sim 0.8$ and $\sim 0.2$ that we considered for the data from the Solar village and Ispra, when we were looking to their similarity with the IASBS site data. In other words one can say that about $80 \%$ of the aerosols in the atmosphere of Zanjan are dust particles and the rest are anthropogenic aerosols.

It can be seen from Fig. 6 for clean conditions, i.e. small $\operatorname{AOD}(440 \mathrm{~nm})$, there is a wide range of $\alpha_{2}-\alpha_{1}$ values (from 0.01 to 1.58 ) for all aerosol types. This is an indication of the existence of bimodal-size distributions at relatively low optical depths.

\section{Conclusions}

The IASBS site has the only SPM operating in a region covered by Iran, Iraq and countries around the Caspian sea. The 2-year data series presented here allows for the first time a climatological approach in the study of AOD, CWV, and the Ångström exponent in the Zanjan area. The average AOD $(440 \mathrm{~nm})$ and CWV for the mentioned period were 0.28 and $0.57 \mathrm{~cm}$, respectively. The maximum (minimum) aerosol optical depth was recorded in May 2007 (November 2007), and the maximum (minimum) CWV occurred in July 2007 (January 2008). A classification for the different aerosol types appearing in Zanjan's atmosphere has been proposed based on the analysis of the AOD and the Ångström exponent features.

A comparison of $\alpha_{2}-\alpha_{1}$ for Zanjan's atmosphere and the SPM measurements for Solar Village and Ispra (Kaskaoutis et al., 2007), indicates that dust and anthropogenic aerosols are the most dominant aerosols in the region, where the former is almost four times of the latter.

Acknowledgements. Authors would like to express their gratitude to the Zanjan Meteorological Office for preparing surface measurements. MODIS Deep Blue aerosol optical depth data used in this study were produced with the Giovanni online data system, developed and maintained by the NASA Goddard Earth Sciences (GES) Data and Information Services Center (DISC). Authors are also grateful to Bahman Farnudi for valuable discussions and his comments on the manuscript.

Edited by: F. Boersma 


\section{References}

Ångström, A. K.: On the atmospheric transmission of sun radiation and on the dust in the air, Geogr. Ann., 12, 130-159, 1929.

Bruegge, C. T., Conel, J. E., Green, R. O., Margolis, J. S., Holm, R. G., and Toon, G.: Water vapor column abundance retrievals during FIFE, J. Geophys. Res., 97, 18759-18768, 1992.

Burrows, J. P., Richter, A., Dehn, A., Deters, B., Himmelmann, S., Voigt, S., and Orphal, J.: Atmospheric remote -sensing-reference data from GOME: 2. Temperature-dependent absorption cross sections of $\mathrm{O}_{3}$ in the 231-794 $\mathrm{nm}$ range, J. Quant. Spectrosc. Ra., 61, 509-517, 1999.

Dubovik, O., Holben, B. N., Eck, T. F., Smirnov, A., Kaufman, Y. J., King, M. D., Tanré, D., and Slutsker, I.: Variability of absorption and optical properties of key aerosol types observed in worldwide locations, J. Atmos. Sci., 59, 590-608, 2002.

Eck, T. F., Holben, B. N., Reid, J. S., Dubovic, O., Smirnov, A., O'Neill, N. T., Slutsker, I., and Kinne, S.: The wavelength dependence of the optical depth of biomass burning, urban and desert dust aerosols, J. Geophys. Res., 104, 31333-31350, 1999.

Eck, T. F., Holben, B. N., Dubovic, O., Smirnov, A., Slutsker, I., Lobert, J. M., and Ramanathan, V.: Column-integrated aerosol optical properties over the Maldives during the northeast monsoon for 1998-2000, J. Geophys. Res., 106, 28555-28566, 2001.

Halthore, R. N., Eck, T. F., Holben, B. N., and Markham, B. L.: Sun-photometric measurements of atmospheric water vapour column abundance in the 940-nm band, J. Geophys. Res., 102, 4343-4352, 1997.

Holben, B. N., Eck, T. F., Slutsker, I., Tanre, D., Buis, J. P., Setzer, A., Vermote, E., Reagan, J. A., Kaufman, Y. J., Nakajima, T., Lavenu, F., Jankowiak, I., and Smirnov, A. : AERONET-A federated instrument network and data archive for aerosol characterization, Remote Sens. Environ., 66, 1-16, 1998.

Kaskaoutis, D. G., Kambezidis, H. D., Hatzianastassiou, N., Kosmopoulos, P. G., and Badarinath, K. V. S.: Aerosol climatology: dependence of the Angstrom exponent on wavelength over four AERONET sites, Atmos. Chem. Phys. Discuss., 7, 7347-7397, doi:10.5194/acpd-7-7347-2007, 2007.

Kasten, F. and Young, A. T.: Revised optical air mass tables and approximation formula, Appl. Optics, 28, 4735-4738, 1989.
King, M. D. and Byrne, D. M.: A method for inferring total ozone content from spectral variation of total optical depth obtained with a solar radiometer, J. Atmos. Sci., 33, 2242-2251, 1976.

Leon, J. and Legrand, M.: Mineral dust sources in the surrounding of the North Indian Ocean, Geophys. Res. Lett., 30(6), 1309, 2003.

McPeters, R. D., Bhartia, P. K., Krueger, A. J., Herman, J. R., Wellemeyer, C. G., Seftor, C. J., Jaross, G., Torres, O., Moy, L., Labow, G., Byerly, W., Taylor, S. L., Swissler, T., and Cebula, R. P.: Earth Probe Total Ozone Mapping Spectrometer (TOMS) Data Products User's Guide, website: http://www.jwocky.gsfc. nasa.gov/, last access: 30 October 2008, Goddard Space Flight Center Greenbelt, Maryland, 20771, 1998.

Mortazavy, F.: Characterizing the resources and type of aerosols in the Zanjan atmosphere using - the data recorded by a sunphotometer, Hysplit4 and Giovanni Models, M. Sc., IASBS, Zanjan, Iran, 2009.

Prospero, J. M., Ginoux, P., Torres, O., Nicholson, S. E., and Gill, T. E.: Environmental characterization of global sources of atmospheric soil dust identified with the NIMBUS 7 Total Ozone Mapping Spectrometer (TOMS) absorbing aerosol product, Rev. Geophys., 40, 1002-1029, 2002.

Samimi, J. and Anvari, A.: Envestigation and analysis of solar energy information and its potantioal in Iran, Tech. Report, Center for energy studies, Iran, 1997.

Schuster, G. L., Dubovik, O., and Holben, B. N.: Ångström exponent and bimodal aerosol size distributions, J. Geophys. Res., 111, 07207, doi:10.1029/2005JD006328, 2006.

Smirnov, A., Holben, B. N., Eck, T. F., Dubovik, O., and Slutsker, I.: Cloud Screening and quality control algorithms for the AERONET database, Remote Sens. Environ., 73, 337-349, 2000.

Smirnov, A., Holben, B. N., Lyapustin, A., Slutsker, I., and Eck, T. F.: AERONET processing algorithms refinement, AERONET Workshop, El Arenosillo, Spain, 10-14 May, 2004.

Toledano, C., Cachorro, V. E., Berjon, A., de Frutos, A. M., Sorribas, M., de la Morena, B. A., and Goloub, P.: Aerosol optical depth and Ångström exponent climatology at "El Arenosillo" AERONET site (Huelva, Spain), Q. J. Roy. Meteorol. Soc., 133, 795-807, 2007. 